${ }^{1}$ Management of Federal Drug Control Service of Russia in Sverdlovsk region. Stepan Razin Str., 31, Ekaterinburg, 620142, Russia.

${ }^{2}$ Ural Federal University, Institute of Chemical Technology, Mira Str., 19, Ekaterinburg, 620002, Russia.

\title{
Differentiation of 2- and 6-isomers of (2-dimethylaminopropyl)benzofuran by tandem mass spectrometry
}

Reliable identification of new psychoactive substances of 2-(2-methylaminopropyl) benzofuran and 6-(2-methylaminopropyl)benzofuran is problematic when analyzing by gas chromatography-mass spectrometry method. It found that these two isomers can be reliably differentiated by MS/MS spectra obtained by collision-induced dissociation of their protonated molecules.

Key words: new psychoactive substances; amphetamine derivatives; chromatography mass spectrometry method; high-resolution mass spectrometry; El spectra; CID spectra.

\author{
В. А. Шевырин ${ }^{1,2}$ \\ ${ }^{1}$ Уравление ФСКН России по Свердловской области. \\ Россия, 620142, Екатеринбург, ул. Степана Разина, 31. \\ ${ }^{2}$ уральский Федеральный университет, \\ Химико-технологический институт. \\ Россия, 620002, Екатеринбург, ул. Мира, 19.
}

\section{Дифференциация 2- и 6-изомеров (2-метиламинопропил)бензофурана методом тандемной масс-спектрометрии}

Достоверная идентификация новых психоактивных соединений 2-(2-метиламинопропил) бензофурана и 6-(2-метиламинопропил)бензофурана проблематична при проведении анализа методом хроматомасс-спектрометрии. Установлено, что эти два изомера могут быть надежно дифференцированы по MC/MC спектрам, полученным в результате диссоциации, индуцируемой соударением, их протонированных молекул.

Ключевые слова: психоактивные соединения; производные амфетамина; хроматомассспектрометрия; масс-спектрометрия высокого разрешения, масс-спектры электронной ионизации, МС/МС спектры.

(C) Shevyrin V. A., 2016

The compounds of 2-aminopropylbenzofuran appeared on the illegal market of new psychoactive substances (NPS) starting in 2010 [1, 2]. Among the most known (Fig. 1) there are two isomers: 5-(2-aminopropyl)benzofuran (5-APB) and 6-(2-aminopropyl)benzofuran (6-APB) as well as their $N$-methyl derivatives (5-MAPB and 6-MAPB, respectively). The compounds 5-APB and 
6-APB are serotonin receptor agonists and their pharmacological effects are similar to amphetamine-type stimulants $[3,4]$. In the territory of the Russia the circulation of 5-APB, 6-APB and these N-methyl derivatives is controlled by legislation.

Since mass spectra of electron ionization (EI) of isomeric compounds of 2-aminopropylbenzofuran have very significant similarity, the question of differentiation of these compounds is the important practical problem associated with the reliable identification of the compounds and their metabolites. When conducting analysis by gas chromatography-mass spectrometry using typical gas chromatography columns for drug identification with dimethylpolysiloxane nonpolar stationary phase (such as HP-5) the<smiles>CC(N)Cc1ccc2occc2c1</smiles>

5-APB<smiles>CNC(C)Cc1ccc2occc2c1</smiles>

5-MAPB differentiation of compounds 5-APB and 6-APB or 5-MAPB and 6-MAPB is possible due to the differences in the values of parameters of the chromatographic retention of these compounds (Fig. 2) or their acyl derivatives $[3,4]$.

First in Autumn of 2015 we found in the illegal trafficking another compound, isomeric 5-MAPB and 6-MAPB, namely 2-(2-methylaminopropyl)benzofuran (2-MAPB), whose structure was reliable established using high-resolution mass spectrometry and two-dimensional NMR spectroscopy.

Compound 2-MAPB (Fig. 3) has not only very similar to the 6-MAPB EI mass spectrum (Match factor more than 900) but the same chromatographic retention parameters (retention index of the<smiles>CC(N)Cc1ccc2ccoc2c1</smiles>

6-APB

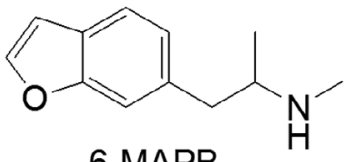

6-MAPB

Fig. 1. Chemical structures of most common derivatives of 2-aminopropylbenzofuran on the illegal market

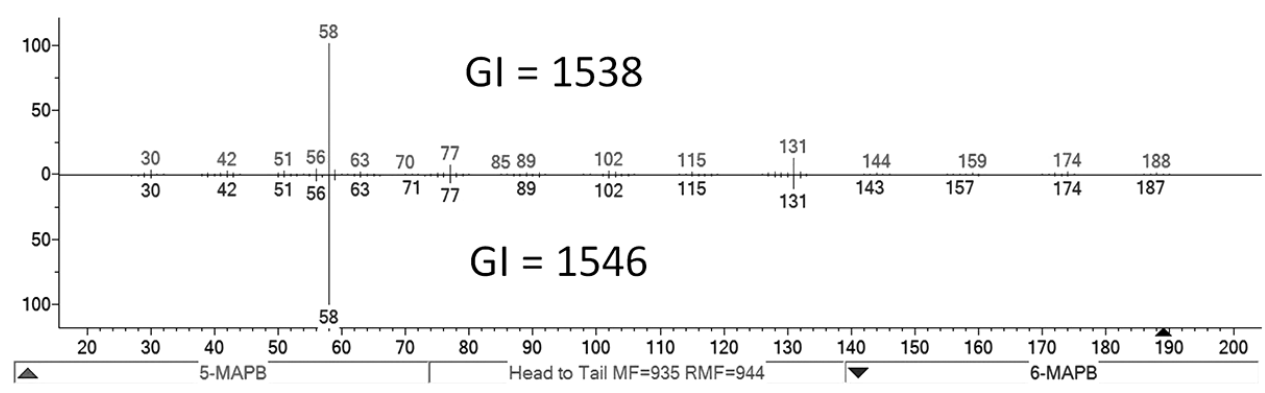

Fig. 2. Comparison EI mass spectra and chromatographic retention indices (GI) of compounds 5-MAPB (top) and 6-MAPB (bottom) according EKBDRUGS library [5] 
compounds GI=1546) [5], which does not allow to distinguish reliably between these compounds. The same values of retention indices were registered by us [5] for methyl (GI=1611) and trifluoroacetyl $(\mathrm{GI}=1749)$ derivatives of 2 -MAPB and 6-MAPB.

To address the question about the possibility of accurate differentiation of 2-MAPB and 6-MAPB using mass spectrometry we have considered different method of mass spectrometric ionization of compounds. As this method the ionization by electrospray was chosen, which is increasingly used in the determination of drugs and their metabolites. Registered in terms of collision-induced dissociation (CID), high resolution MS/MS spectra of protonated molecules of compounds 2-MAPB and 6-MAPB (Fig. 4) and their methyl derivatives had significant differences that allow to identify these compounds easily.

Thus, in the MS/MS spectrum of 2-MAPB as the main product ions with $\mathrm{m} / \mathrm{z} 58,0654(100 \%)$ and $159,0804(1 \%)$ were observed but in MS/MS spectrum of 6-MAPB ions with $\mathrm{m} / \mathrm{z}$ 159,0804 (100\%)

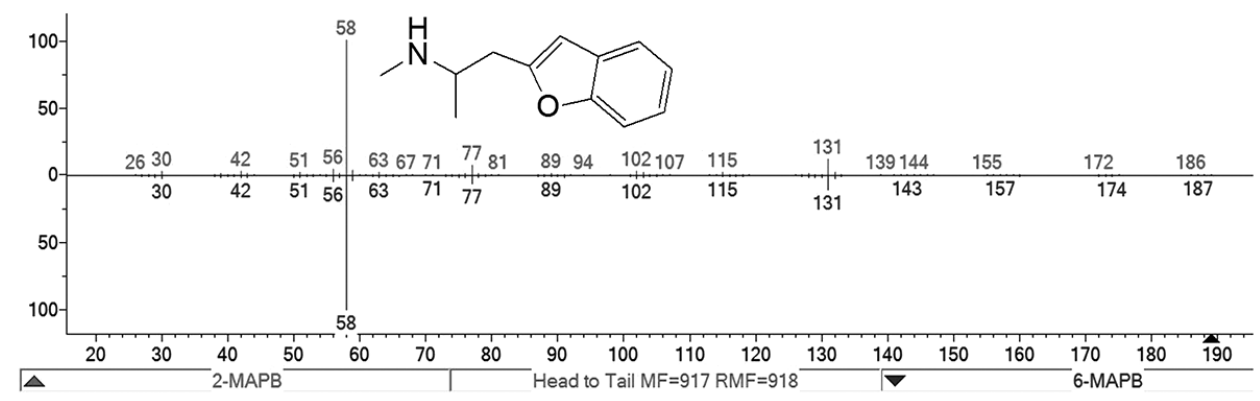

Fig. 3. The chemical structure of the compound 2-MAPB and the comparison of its EI mass spectrum with mass spectrum of 6-MAPB (bottom)

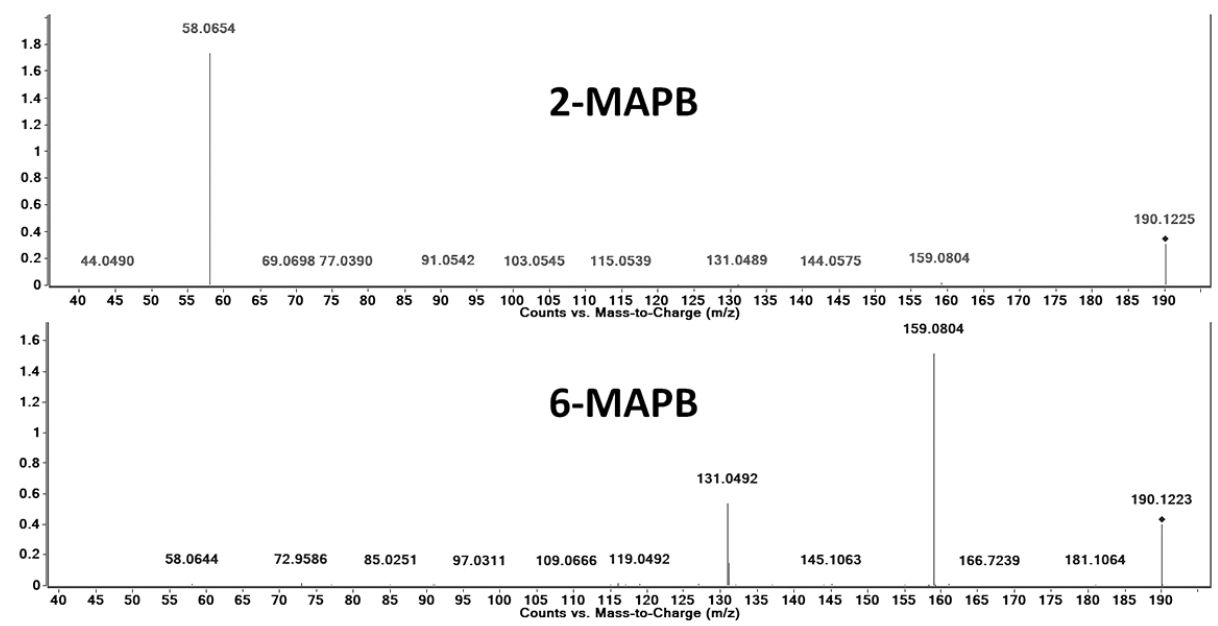

Fig. 4. Comparison of CID spectra of protonated molecules of the compounds 2-MAPB and 6-MAPB 


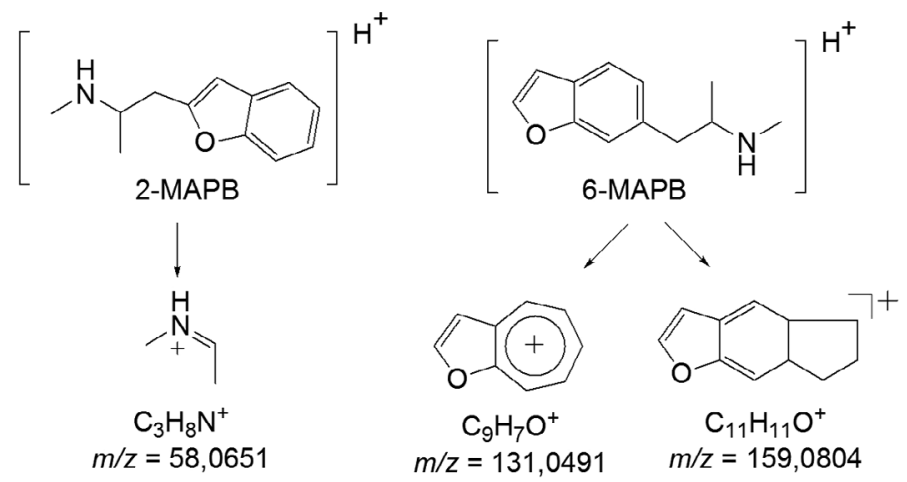

Fig. 5. The probable structure of the major fragment ions in the CID spectra of the compounds 2-MAPB and 6-MAPB

and 131,0492 (36 \%) were observed. The intensity of the ion with $\mathrm{m} / z 58,0644$ in the spectrum of 6-MAPB did not exceed $1 \%$.

The differences in the spectra can be explained by the advantageous formation of stable cyclic structures for ions with $\mathrm{m} / z 159,0804$ and 131,0492 in the case of compound 6-MAPB (Fig. 5). In the case of compound 2-MAPB alternative process with the formation of ion with $\mathrm{m} / \mathrm{z}$ 58,0654 is favorable.

Thus, additional check CID spectra of protonated molecules of compounds 2-MAPB and 6-MAPB allow to differentiate these isomers reliably.

\section{In russian}

Соединения 2-аминопропилбензофурана появились на нелегальном рынке новых психоактивных соединений (НПС), начиная с 2010 года $[1,2]$. Среди них наиболее известны (рис. 1) два изомера, 5-(2-аминопропил)бензофуран (5-АРВ) и 6-(2-аминопропил)бензофуран (6-АРВ), а также их $N$-метильные производные (5-МАРВ и 6-МАРВ, соответственно). Соединения 5-АРВ и 6-АРВ являются антагонистами серотониновых рецепторов и по своему фармакологическому действию подобны стимуляторам амфетаминового ряда [3, 4]. На территории России оборот 5-АРВ, 6-АРВ и их $N$-метильных производных контролируется законодательством.
Поскольку масс-спектры электронной ионизации изомерных соединений 2-аминопропилбензофурана обладают весьма значительным сходством, вопрос дифференциации этих соединений представляет собой важную практическую проблему, связанную с достоверной идентификацией как самих соединений, так и их метаболитов. При проведении анализа методом хроматомасс-спектрометрии с использованием типичных для определения наркотиков газохроматографических колонок с неполярной диметилполисилоксановой неподвижной фазой (типа НР-5) дифференциация соединений 5-АРВ и 6-АРВ, или 5-МАРВ и 6-МАРВ возможна за счет различия 
значений параметров хроматографического удерживания этих соединений (рис. 2), а также их ацильных производных $[3,4]$.

Осенью 2015 года в нелегальном обороте нами впервые было обнаружено еще одно соединение, изомерное 5-МАРВ и 6-МАРВ, а именно 2-(2-метиламинопропил)бензофуран (2-МАРВ), структура которого была достоверно установлена с использованием масс-спектрометрии высокого разрешения и двумерной ЯМР-спектроскопии.

Соединение 2-МАРВ (рис. 3) обладает не только очень сходным с 6-МАРВ масс-спектром электрон- ной ионизации (Match фактор более 900), но и одинаковыми параметрами хроматографического удерживания (индекс удерживания соединений $\mathrm{GI}=1546)$ [5], что не позволяет надежно различить эти соединения. Одинаковые значения индексов удерживания зарегистрированы нами [5] также для метильных (GI=1611) и трифторацетильных (GI=1749) производных 2-МАРВ и 6-МАРВ.

Для решения вопроса о возможности достоверной дифференциации 2-МАРВ и 6-МАРВ с использованием масс-спектрометрии нами был рассмотрен иной масс-спектрометрический метод ионизации соединений. В ка-<smiles>CC(N)Cc1ccc2occc2c1</smiles>

5-APB<smiles>CNC(C)Cc1ccc2occc2c1</smiles>

5-MAPB<smiles>CC(N)Cc1ccc2ccoc2c1</smiles>

$6-A P B$<smiles>CNC(C)Cc1ccc2ccoc2c1</smiles>

Рис. 1. Химические структуры наиболее распространенных на нелегальном рынке производных 2-аминопропилбензофурана

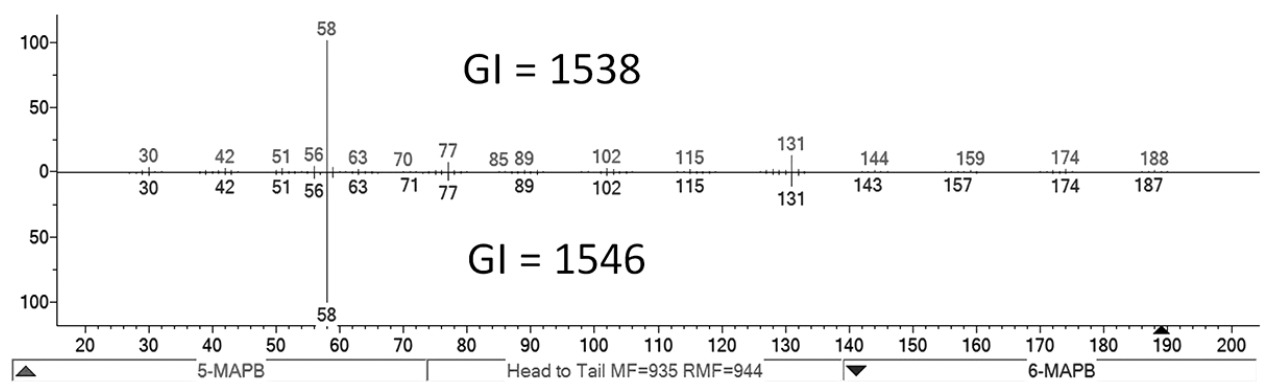

Рис. 2. Сравнение масс-спектров электронной ионизации и индексов хроматографического удерживания (GI) соединений 5-MAPB (вверху) и 6-MAPB (внизу), по данным библиотеки EKBDRUGS [5] 
честве такого метода была выбрана ионизация электрораспылением, все более активно применяемая при определении наркотических средств и их метаболитов. Зарегистрированные в условиях диссоциации, индуцируемой соударением (ДИС), МС/MC спектры высокого разрешения протонированных молекул соединений 2-МАРВ и 6-МАРВ (рис. 4), а также их метильных производных, имели существенные различия, позволяющие легко идентифицировать эти соединения.

Так, в МС/MC спектре 2-MAРВ в качестве основных ион-продуктов на- блюдаются ионы с $\mathrm{m} / z$ 58,0654 (100 \%) и 159,0804 (1\%), а в MC/MC спектре 6-МАРВ - ионы с $\mathrm{m} / z$ 159,0804 (100 \%) и 131,0492 (36 \%). Интенсивность иона с $m / z 58,0644$ в спектре 6-МАРВ не превысила $1 \%$.

Различия в спектрах могут быть объяснены выгодным образованием стабильных циклических структур для ионов с $m / z 159,0804$ и 131,0492 в случае соединения 6-МАРВ (рис. 5). В случае соединения 2-МАРВ благоприятен альтернативный процесс с образованием иона с $m / z 58,0654$.

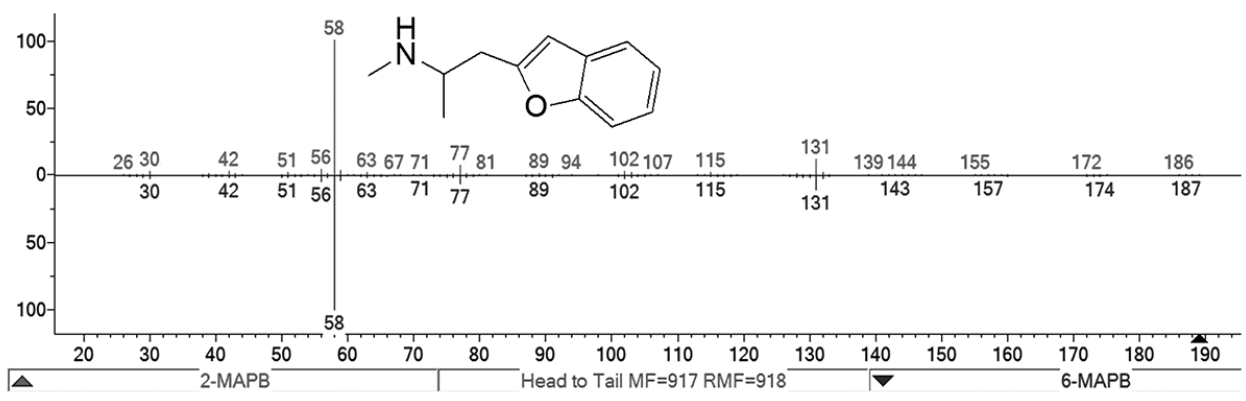

Рис. 3. Химическая структура соединения 2-МАРВ и сравнение его масс-спектра электронной ионизации с масс-спектром 6-МАРВ (внизу)
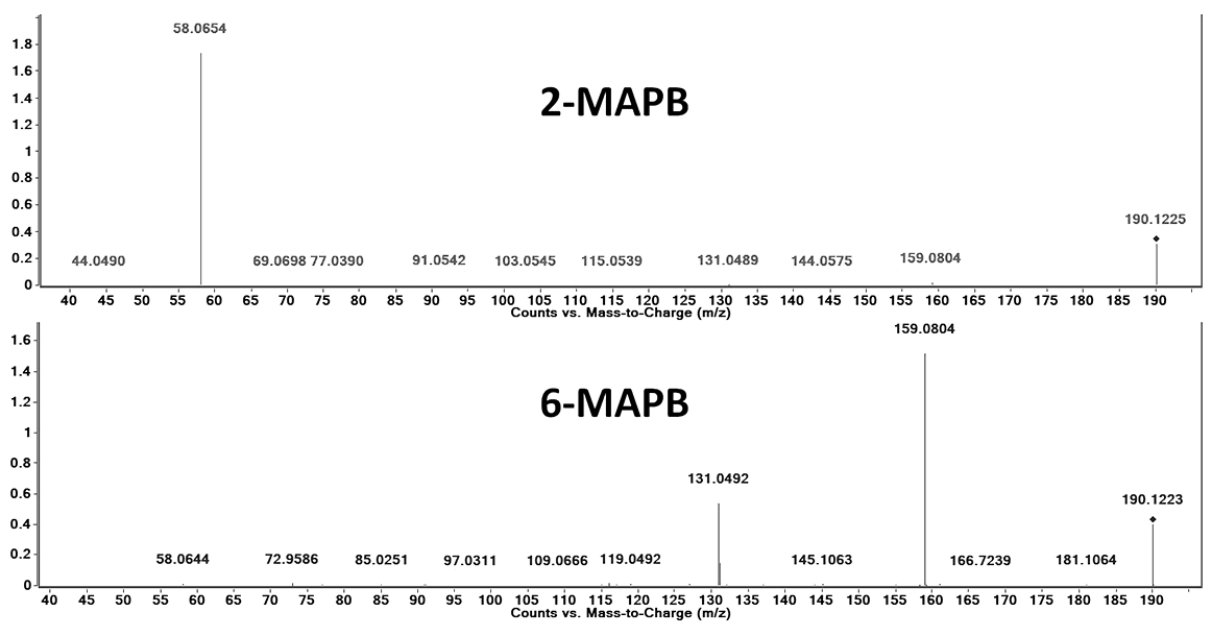

Рис. 4. Сравнение спектров ДИС протонированных молекул соединений 2-МАРВ и 6-МАРВ 

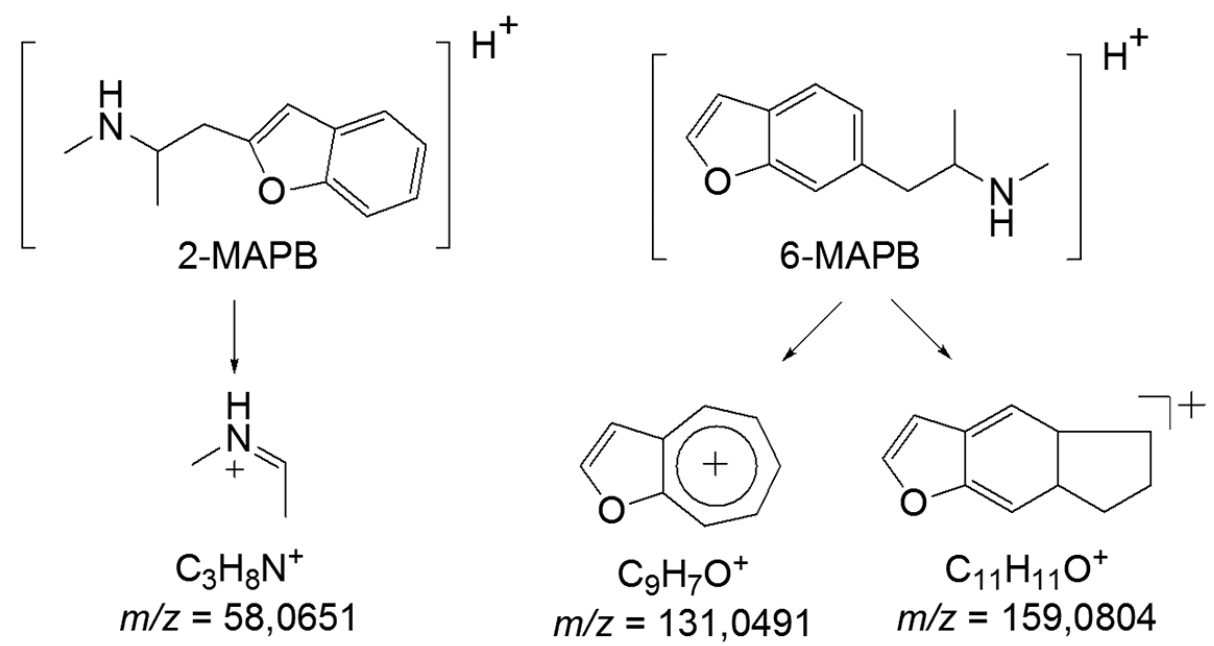

Рис. 5. Вероятные структуры основных фрагментных ионов в спектрах ДИС соединений 2-МАРВ и 6-МАРВ

Таким образом, дополнительная регистрация спектров ДИС протонированных молекул соединений 2-МАРВ и 6-МАРВ позволяет достоверно дифференцировать эти изомеры.

\section{References}

1. King L. A. New phenethylamines in Europe. Drug Test. Anal. 2014;6(7-8): 808-818. DOI: $10.1002 /$ dta.1570.

2. Casale J. F., Hays P. A. The characterization of 6-(2-aminopropyl)benzofuran and differentiation from its 4-, 5-, and 7-positional analogues. Microgram J. 2012;9(2):61-74.

3. Welter J., Kavanagh P., Meyer M. R., Maurer H. H. Benzofuran analogues of amphetamine and methamphetamine: studies on the metabolism and toxicological analysis of 5-APB and 5-MAPB in urine and plasma using GC-MS and LC-(HR)-MSn techniques. Anal. Bioanal. Chem. 2015;407:1371-1388. DOI: 10.1007/s00216-014-8360-0.

4. Welter J., Brandt S. D., Kavanagh P., Meyer M. R., Maurer H. H. Metabolic fate, mass spectral fragmentation, detectability, and differentiation in urine of the benzofuran designer drugs 6-APB and 6-MAPB in comparison to their 5-isomers using GC-MS and LC-(HR)-MSn techniques. Anal. Bioanal. Chem. 2015;407:3457-3470. DOI: $10.1007 / \mathrm{s} 00216-015-8552-2$.

5. Electronic library of mass spectra of electron ionization «EKBDRUGS» (MS LIBRARY EKBDRUGS): certificate of state registration database No. 2015621086 Russia / V. P. Melkozerov, V. A. Shevyrin.

Cite this article as (как цитировать эту статью):

Shevyrin V. A. Differentiation of 2- and 6-isomers of (2-dimethylaminopropyl)benzofuran by tandem mass spectrometry. Chimica Techno Acta. 2016;3(2):156-162. DOI: 10.15826/chimtech.2016.3.2.012. 